\title{
SZIGETVÁRI Oszkár
}

\section{A fővárosi rendőrség detektívtestülete 1885-1918}

( doi: 10.31626/HU-EISSN2530094X.IIITOM.133-162.p)

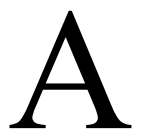

kiegyezéskor a magyar állam nem vette át az idegen elnyomás kivitelezését is megvalósító, centrális vezetés alatt álló birodalmi rendvédelmi testületek magyarországi szervezeteit. ${ }^{1}$ Ehelyett - a municipálisok és a centralisták között megvalósított reformkori közigazgatás elméleti vita nyomán ${ }^{2}$ - a rend védelmét az önkormányzatok kompetenciájába helyezték, ezzel lénygében befejezve azt a folyamatot, amely a neoabszolutizmus enyhébb szakaszában 1861-töl már elkezdődött a rendvédelem terén. A rendvédelemnek mint feladatnak önkormányzati hatáskörbe sorolásáról a köztörvényhatóságok rendezéséről szóló 1870 . évi, valamint a községek rendezéséröl szóló 1871. évi törvények rendelkeztek. ${ }^{3}$ A polgári magyar állam időszakában a központi államhatalom közvetlen alárendeltségében 13 rendvédelmi testület müködött, közülük a rendőrségek, a csendőrség, a pénzügyőrség, a vámörség, a folyamőrség és a határörség rendelkezett kisebb-nagyobb nyomozó munkára specializált szervezeti egységekkel. ${ }^{4}$

Az önkormányzati modell azonban a dualizmus idejében megbukott, ezért a rendvédelem átszervezése elkezdődött. Elöször a falvakban, majd a városokban indult el a központosítás folyamata, megkezdődött az államosítás. ${ }^{5} \mathrm{~A}$ fővárosi rendőrségnek kiemelkedő szerepe volt a magyar állami rendőrség létrehozásában, mivel a budapesti rendőrséget már 1872-ben ideiglenesen, majd 1881-ben véglegesen államosították. ${ }^{6}$

Szilárd talaj állt tehát rendelkezésre 1881-ben a fövárosi rendőrség államosításához. Az államosítást elrendelő törvény részletesen szabályozta a rendőrség eljárását, a szervezeti szabályokat, melyekre nézve korábban az úgynevezett „Sárga könyv" adott gyakorlati útmutatást. A fövárosi rendőrség a bünesetek felderítésében nem jeleskedett, bünügyi nyilvántartó és jól képzett detektívek híján alulmaradt a kihívásokkal szemben. Akadtak ugyan kitünő nyomozói adottságokkal megáldott rendbiztosok, ${ }^{8}$ akik sikerrel derítettek fel bünügyeket, de ez önmagában egy átfogó eredmény eléréséhez nem volt elegen- 
dő. A rendőrség figyelmét lekötötték az utcai mozgalmak zavargásainak kezelése, detektív-tanfolyamok nem voltak, az egyenruhás örszemélyzet kapacitása és képzetlensége révén alkalmatlan volt nyomozó munka végzésére.'

A rendőrségnek és szolgálati ágainak fejlődése során a kezdeti, úgymond hagyományos rendőri jelleget igénylő feladatok mellett szembe kellett nézni az egyéb új képességeket, tulajdonságokat igénylő kihívásokkal is. Az új feladatok fedett tevékenységet, vagy a rendőri jelleg leplezését, esetleg egyéb nem nyílt információszerzést igényeltek a siker érdekében. E kihívásokat felismerve, ezekre reagálva alakult meg a polgári magyar állam detektív testülete, miután a detektív munka jogszabályi környezete is rendezésre került. 1880-ban életbe lépett a Magyar Büntetötörvénykönyv, amely felváltotta a korábbi „Sárga könyv”-et. Ezzel pedig ezen jogterületnek a kor nemzetközi élvonalába tartozó magyar jogi szabályrendszere jött létre. ${ }^{10}$

TÖRÖK János rendőr-fökapitány felismerve a rendőrség hiányosságait, a bünügyi helyzetre reagálva 1885 . XII. 15-én - TISZA Kálmán miniszterelnök és belügyminiszter utasítására — felállította a detektívosztályt, amely 1886. I. 01-én kezdte meg müködését. ${ }^{11}$

TÖRÖK János budapesti rendör-fökapitány a fővárosi rendőrség személyi állományának átszervezés előtti kiválóságait megtartva és szorgalmas, becsületes és tehetséges újonnan felvett rendőrökkel gyarapítva a testület létszámát lényegében új rendőrséget hozott létre. A detektívtestület kezdetben 28 föt számlált, majd további 8 detektívet vettek fel, ezzel párhuzamosan pedig a polgári biztosok intézményét megszüntették.

A detektívosztály vezetőjévé SPLÉNYI Ödön címzetes kerületi rendőr-kapitányt nevezték ki felügyelői címmel, ezzel önálló testületté vált az osztály. TÖRÖK János budapesti rendőr-fökapitány 1886-ban kiadott rendeletének értelmében az összes kinevezett detektívet a detektívosztályba sorolták be. Korábban — szolgálati utasítás hiányában — a detektívek a főkapitányság közvetlen vagy a kerületi a kapitányságok alárendeltségében látták el feladatukat. SPLÉNYI Ödön rendelke- 
zése szerint a fökapitány mellé és a Margitszigetre 1-1, a bünügyi osztályra 12, az államrendészethez 1 , a detektívfelügyelő mellé 4, szolgálatvezetésre 1, a bérkocsisok felügyeletére 2, a prostitúció ellen-őrzésére 2, a vendéglök és vasutasok megfigyelésére 4, a detektív örjárati szolgálatra pedig 8 került beosztásra. ${ }^{12}$

A létszámot folyamatosan bővítették, ami 1911-ben már 190 főre duzzadt, majd év végére további 83 detektív került kinevezésre, 1914-ben pedig elérte a 250 föt. 1919-re a folyamatos bővítéseknek köszönhetően 543 fö detektív látott el szolgálatot. A fővárosi rendőrség detektív testületét 1918 végéig egymást követően 6 detektívfönök vezette. ${ }^{13}$

A szolgálat szervezésében megjelentek a csoportbeosztások, melynek előnye, hogy képességeik alapján szelektálták az embereket és párosították hozzájuk az elvégzendő feladatokat. Tehát a felmerülő feladatot az arra legalkalmasabb detektívek végezhették. Megkezdődött a detektívtestületen a specializáció, amely napjaink nyomozói körében is megfigyelhető. Természetesen mindenki másban volt tehetséges ezért nem felváltva végezték immár a feladatokat (puhatolás, megfigyelés), a detektívek a nekik leginkább testhezálló tevékenységet folytatták. Ennek szervezését a csoportvezetők végezték, akikhez 3-4 fő detektív tartozott. A specializáció előnye volt továbbá, hogy bizonyos tevékenységeket tökélyre lehetett fejleszteni annak állandó müvelése folytán, megteremtve ezzel a sikeres bünüldözés alapjait. ${ }^{14}$

A főcsoportok tagozódásuk szerint sérülési föcsoport (emberölési ügyek, közlekedési balesetek, személy elleni büncselekménye), intellektuális föcsoport (csalás, sikkasztás, hamisítási ügyek), valamint lopási és betörési föcsoportok voltak. Külön föcsoport foglalkozott az állambiztonsági és sajtöügyekkel. A detektívek müködési körére tekintettel kirendeltségeik lefedték a fővárost és annak kiemelt fontosságú és forgalmú pontjai közelében voltak találhatóak. (Keleti, Déli, Nyugati pályaudvarok, Valutaügynökség stb. $)^{\mathbf{1 5}}$

A rendvédelmi oktatás — tekintetében figyelembe véve az 1867-1945 közötti időszakot, — nem kívánták beépíteni a 
rendvédelmi szakképzést az állami iskolai rendszerbe. A különböző beosztásokhoz meghatározott állami iskolai végzettséggel kellett rendelkezni, ezt követően kerülhetett sor az adott beosztás betöltéséhez előírt szaktanfolyam elvégzésére. Ennek alapjait a köztisztviselő minősítéséről szóló 1883. évi törvény szabályozta, ${ }^{16}$ amely az állami alkalmazottak képesítési követelményeit határozta meg. Az elöírt feltételek biztosították a személyi állomány magas fokú képzettségét, felkészültségét. Továbbá rendkívül költségtakarékos megoldás volt a szaktanfolyami rendszer, hiszen a polgári oktatás intézményein alapult, így nem emésztett fel többletköltségeket rendvédelmi felsőfokú oktatási intézmények müködtetése. ${ }^{17}$

A detektívek képzési rendszere elsősorban a jelentkezők személyes képességeire és adottságaira épült. Képességeik felmérése alapján elsősorban a detektívfőnök döntötte el, hogy a próbaszolgálatot követően, melyik csoportba kerülnek beosztásra a gyakornokok. Egy-két év gyakorlat után - melyet folyamatos monitorozás kísért — dőlt el, hogy véglegesen megmarad-e a gyakornok az eredeti csoportban, esetleg másik büncselekményekkel foglalkozó csoportba kerül, netán a legroszszabb esetben nem megfelelő teljesítmény nyújtása esetén elbocsátják.

A tanfolyamok és szakvizsgák alapjai már 1890-ben megjelentek, intézményi szabályozására belügyminiszteri rendelettel, azonban csak 1923-ban a háború után került sor.

Ennek értelmében a detektív testület tagjai számára kétféle tanfolyamot és vizsgát a detektív és a detektívfelügyelöit rendszeresítették. Az alap detektívtanfolyam keretén belül a résztvevők többek között közigazgatási ismereteket, kriminalisztikát, büntetőjogot hallgattak, megismerkedtek a szolgálati szabályzattal, lövészetet, birkózást és egyéb gyakorlati ismereteket is szereztek. Boncoláson vettek részt, hogy megismerjék az emberi test anatómiáját, mellyel szintén a gyakorlatban használható fontos tudás birtokába kerültek. A detektívfelügyelői tanfolyam részletesebb és mélyebbre menő ismeretanyaggal szolgált, melyben az önálló munkavégzésre és vezetésre alkalmas kiválasztottak részesültek, ez a későbbi elő- 
rehaladás egyik lépcsőfoka volt. A tanfolyamok szóbeli és írásbeli vizsgával zárultak. ${ }^{18}$

Fegyverzet vonatkozásában a fövárosi rendőrség detektívtestületét csupán maroklőfegyverrel szerelték fel. Az örszolgálati állományt azonban gépkarabéllyal is ellátták. ${ }^{19}$

Mivel a detektív státuszok képesítési előfeltétele az állami iskolai végzettség tekintetében az érettségi volt, ezért a detektíveket besorolták az állami fizetési osztályokba. Ebből fakadóan pedig a detektívek számára biztosították a társadalmi állásukhoz méltó életvitelhez szükséges feltételeket. Fizetésük alkalmas volt egy család tisztes megélhetési költségeinek a fedezésére. Az általuk betöltött beosztás szintjétől és családjuk nagyságától függő alapterületủ és komfortfokozatú lakás lakbérének a teljes összegét megtérítette számukra az állam függetlenül attól, hogy az ország mely pontján teljesítettek szolgálatot. Emellett fizetésük 100 \%-val voltak nyugdíjjogosultak 40 évi szolgálat után. Fizetésük néhány \%-os befizetése ellenében pedig ők és közvetlen családtagjaik teljes körü orvosi ellátásra tarthattak igényt. A detektívek számára tehát az állam - más alkalmazottaihoz hasonlóan — biztosította azokat a feltételeket, amelyek mentesítették a detektíveket a hétköznapi megélhetési gondok súlya alól. ${ }^{20}$

A fővárosi rendőrség detektív testületének nemcsak a szervezete és a létszáma fejlődött dinamikusan, illetve halmozódtak fel - a testület kötelékében szolgálatot teljesítő detektívek körében - a szakmai tapasztalatok, hanem a jogszabályi környezet is dinamikusan fejlődött. Létrejött a bünvádi perrendtartásról szóló 1896. évi törvény, amely — számos hasznos részlet szabályozása mellett - olyan alapfogalmakat is tisztázott, mint a rendőrhatóság fogalma $s t b .{ }^{21} \mathrm{E}$ törvény nyomán pedig a belügyminiszter szabályozta a rendőrhatósági jogköröket, annak részeként a nyomozó tevékenységet is. ${ }^{22}$

A nyomozó rendőri hatóságok és közegek részére kiadott 1899. évi belügyminiszteri rendelet részletesen írta le a nyomozás feladatait. Ennek értelmében a nyomozás feladata a tényállás megállapítása és az adatok összegyüjtése, ami alapján a bíróság vizsgálata mellőzhető, illetve elegendő informá- 
ció összegyüjtése a bíróság döntéséhez. RUDNAY Béla budapesti állami rendőrség főkapitányának beszámolója szerint az 1881-es szabályozáshoz képest az 1896. évi büntető perrendtartási törvény bővíti a rendőrség hatáskörét, ebböl kifolyólag több feladatot ró a testületre.

A beszámoló alapján a bünügyi osztály tekintetében 1899-ben 67059, 1900-ban pedig 88556 ügyirat keletkezett. ${ }^{23}$

Tehát már ekkor is megfigyelhető, hogy a változó törvényi háttér által a nyomozati jogkörrel rendelkező szerveknek egyre több feladattal kellett szembenézniük.

A detektívek munkáját nagymértékben megkönnyítette az 1885-ben létrehozott bünügyi nyilvántartás, ami számos egyéb újításhoz hasonlóan TÖRÖK János főkapitány nevéhez füződik. Ennek alapját a korábban rendőrök által készített magánfeljegyzések alkották. KoVICS Károly budai főkapitány például a városegyesítést megelözően készített feljegyzéseket a megrögzött bünösökröl, fertőzött területekről, bủnjelekről. A nyilvántartás négy részből állt: körözött személyek és rovott múltúak, lopott és talált tárgyak, feltételesen szabadlábra bocsátottak, valamint a rendőri közlönyök nyilvántartásából. A nyilvántartás ekkor még teljes egészében a detektívosztály kezelésében volt. 1887-ben került kiegészítésre egy fényképes arcképnyilvántartással, továbbá rögzítésre kerültek az ismerté vált játékbarlangok, búvóhelyek. Az elkészült fényképek és a társítandó személyek problematikája felmerült, mivel a gyanúsítottak sokszor nem valós adataikat közölték. 1908-ban föleg a budapesti gyüjteményre támaszkodva országos nyilvántartás került bevezetésre. 1897-ben felmerült a Bertillon módszer bevezetésének lehetősége, melynek érdekében megkezdték az előkészületeket. ${ }^{24}$ Az erről szóló szakkönyv fordítását megkezdték, GÁRDONYI Viktor detektív pedig Párizsban elvégezte a Bertillon iskolát, melyet Ausztriában, Németországban és Franciaországban már alkalmaztak. Ténylegesen a módszer azonban nem került bevezetésre, mivel időközben dr. PEKÁRY Ferenc kerületi kapitány 1902-ben Londonban megismerte a GALLTON-módszert, ami használhatóbb és pontosabb volt a korábbi lehetőségeknél. 
Az Indiából származó - ujjlenyomat alapján történő azonosítás során - tulajdonképpen egy horganylemezre tintát terítettek szét gumihengerrel, amibe az ujj lenyomatát helyezve minden ember esetében eltérő jellemző alapján nyílt lehetőség az azonosításra.

Fenti okoknál fogva hazánkban a GALLTON-féle azonosítási technika került bevezetésre. Ezzel Anglia után Európában Budapesten vezették be elöször a daktiloszkópiai azonosítást. 1902-ben bevezetésének évében 2000 lenyomat került levételre, melyet követően több esetben sikerült beazonosítani álnevet használó törvényszegőket. A daktiloszkópia nyilvántartást a fényképek és egyéb feljegyzések nyilvántartások kiegészítették, azok együttes használata precízebb, alaposabb és biztosabb rendőri munkát tett lehetővé. ${ }^{25}$

A mai nyomozómunkában mindennapossá vált, álcázás, leplezés, rendőri mivolt elhallgatása, a korai detektívek körében is sokszor alkalmazott és bevált módszer volt. A detektívek gyakorta öltöztek előkelő uraknak, gázóra leolvasónak, koldusnak, sőt hölgyeknek is. ${ }^{26}$

A budapesti detektívek eredményes felderítéséből említésre méltó a több országban körözött betörők PAPAKOSTA és társainak elfogása, az 1884-ben történt postarablás elkövetöjének, CSOMBOR Imrének a felkutatása és kézre kerítése. ${ }^{27}$

Az életellenes cselekmények sikeres nyomozásának ékes példája az 1909-ben Adria szállóban meggyilkolt prostituált esete. Az elkövetőt a fövárosi detektívek néhány óra leforgása alatt, a mai szakmai zsargont alkalmazva forró nyomon üldözéssel kerítette kézre. Ebben az évben Budafokon lőttek le egy kocsmárost ismeretlen elkövetők, akiket egy napi nyomozás után sikerült elfognia a testület tagjainak. Említésre méltó a megfigyelö-szolgálat kiépítése is, melynek során a detektívek figyelemmel tartották azokat a kétes hírü helyeket, játékbarlangokat, rendezvényeket, italmérő egységeket, ahol a rovott múltú vagy körözött, esetleg a közbiztonságot veszélyeztető elemek megfordulhattak. A megfelelő információk birtokában sor kerülhetett a zálogházi és egyéb inkriminált helyeken raz- 
ziák megszervezésére, melyek alkalmával 1908-ban 500, 1909-ben 862 személyt fogtak el a detektív testület tagjai. ${ }^{28}$

A dualizmus időszakában dinamikusan fejlödő magyar főváros és a bünügyi munkát szabályozó jogszabályok változásai előidézték a detektív testület szabályzatának a fejlesztését is. A detektív osztály első szabályzata - napjaink terminológiája szerinti szervezeti és müködési szabályzata - belügyminiszteri jóváhagyással 1881. VII. 1-én lépett hatályba. ${ }^{29}$ Kilenc évvel később született az újabb detektív szabályzat, melyet 1890. VI. 1-én szintén a belügyi tárca vezetője hagyott jóvá. ${ }^{30}$ Ezzel a fővárosi rendôrségen belül a detektív testület élen járt, hiszen az örszemélyzet (közrendvédelmi állomány) számára külön szervezeti szabályzatát csak 1893-ban léptették életbe. ${ }^{31}$ A dualizmus idején jöttek létre a - fövárosi rendőrséget szabályozó 1884 . évi belügyi utasítás nyomán ${ }^{32}$ - a fóvárosi rendőrség szakszolgálati ágait szabályozó szabályzatok, amelyeket a két világháború közötti időszakban alapvetően már csupán aktualizáltak. ${ }^{33} \mathrm{~A}$ fővárosi rendőrség szervezetére és szolgálatellátására vonatkozó jogszabályok a századfordulóra oly mértékben gyarapodtak, hogy a rendőrök időszerünek tartották a rájuk vonatkozó joganyag összegyüjtését és rendszerezését. Az első ilyen jogszabálygyüjteményt 1896-ban adták ki, majd 1902-ig évente kiegészítették és aktualizálták. Emellett a fővárosi rendőrség 1895-től az éves jelentéseit is publikálta, amelyek magukban foglalták a testületnek a tárgyévre vonatkozó legfontosabb adatait és eseményeit. ${ }^{34}$

A XIX-XX. század fordulóján izmosodó fővárosi rendörség és annak részeként — a mennyiségi és minőségi mutatói tekintetében is gyarapodó - detektív testület nemzetközileg elismert tevékenységet valósított meg. ${ }^{35}$

Figyelemre méltó, hogy a dualizmus időszakában a fökapitányi tisztséget betöltő 8 személy közül 4 fö került ki csupán a fővárosi rendőrség személyi állományából, közülük azonban 2 föt - dr. SÉLLEY Sándort és dr. SÁNDOR Lászlót - közvetlenül a detektív testület éléről neveztek ki rendőr-főkapitánnyá 1892-ben, illetve 1917-ben. ${ }^{36}$ 
A fővárosi rendőrség detektív testülete oly vonzó példa volt, hogy a vidéki városok az önkormányzati rendőrségeik kötelékében sorra állították fel a detektív testületeiket. ${ }^{37}$

A fövárosi detektív testület résztvett az államfő védelmében is. A fővárosi rendőrség detektív testületétől detektív csoportot vezényeltek az uralkodó magyarországi látogatásai kapcsán a magyarországi testőrségekhez. Az Osztrák-Magyar Monarchiának ugyanis nem volt közös államföje, ha-nem a két társország azaz az Osztrák Császárság és a Magyar Királyság rendelkezett egy-egy legfelsőbb közjogi tisztséggel az osztrák császári és a magyar királyi tisztséggel. E két legfelsőbb közjogi méltóságot azonban egyetlen természetes személy Ferenc József töltötte be, akire a császári és a királyi testőrségek egyaránt vigyáztak. Az uralkodó és közvetlen környezete testi épségéért az Osztrák Császárság területén az osztrák testőrségek, a Magyar Királyság területén pedig a magyar testőrségek feleltek. A testőri feladatok ellátásában azonban a társország területén is részt vehetett valamennyi testőrség tagja. A testőrkapitányok a főudvarmester közvetlen alárendeltségébe tartoztak. A korabeli testőrségek — napjaink hasonló szervezetivel összehasonlítva - döntően díszelgő jellegü örzési teendőket valósítottak meg. Ezért szükség volt arra, hogy az esetleges merényletek és rendbontások kivizsgálása, illetve megelőzése céljából tapasztalt detektívek is segítsék a munkájukat. A magyar testőrségek munkáját a fóvárosi rendőrségtől a testülethez vezényelt detektív csoport segítette. Az uralkodó országjárásai esetében azonban a vidéki helyi rendvédelmi szervezetek - így az önkormányzati rendőrségek detektív testületei is együttmüködtek a testőrségekkel. ${ }^{38}$

A fővárosi rendőrséghez hasonlóan — bár attól kissé megkésve - került sor a Magyar Királyi Csendőrségnél is a nyomozói munkára specializált szervezeti részleg létrehozására. Ezek voltak az úgynevezett járásőrmesterségek. Ez a szervezet azonban rövid életünek bizonyult, mivel az I. világháború során — a képzett csendőrök hiánya miatt — a járásőrmesterségeket megszüntették, a világháború után pedig más uta- 
kon haladt a Magyar Királyi Csendőrség nyomozó szolgálatának kiépítése. ${ }^{39}$

A dualizmus idejében - a fövárosi rendőrség mellett a másik állami rendőrség a Magyar Királyi Határrendőrség volt. 1906. januárban kezdte meg müködését a határrendörség, melynek első vezetője CZÁJLIK Alajos budapesti rendőrtanácsos volt. Kezdetben csak egyenruhás állomány teljesített szolgálatot a testületnél, majd 1909-ben 20 detektívállást rendszeresítettek a határrendörségnél, ezzel megvalósítva a központi nyomozás alapjait. ${ }^{40}$

A nagyobb volumenü komplikáltabb bünügyek esetében a vidéki rendőrségek elegendő gyakorlat és tapasztalat hiányában továbbra is a fövárosi rendőrség detektív testületét kérték fel a bonyolult ügyek kinyomozására.

Az I. világháború időszaka - hasonlóan a Magyar Királyság társ rendvédelmi testületeihez, illetve azok detektív testületeihez - külön fejezet a fövárosi detektív testület történetében. Alapvetően három jelenség alakított 1914 és 1915 között a fövárosi rendörség detektív testületének tevékenységét.

Az elsö jelenség a magyarországi kivételes hatalom volt. Kivételes hatalomnak nevezték a kortársak az alapvető jogok korlátozását és az abból fakadó teendőket annak érdekében, hogy háború időszakában maximálisan mozgósíthassák forrásaikat a fegyveres harc eredményes megvívása érdekében. A kivételes hatalom gyakorlásának szabályait — legalább is azok főbb elveit - már békeidőben kimunkálták, így a fegyveres konfliktus kirobbanása esetében csupán érvénybe kellett léptetni a vonatkozó szabályokat illetve az előre nem látható helyzetek rendezése érdekében rendeleteket hozni. Kétféle minta alakult ki Európában a kivételes hatalom gyakorlásának a szabályozására. A brit minta szerint a kivételes hatalom gyakorlásának a jogkörét a kormány gyakorolta. A német minta szerint e jogkörrel a haderőt ruházták fel. Az Osztrák-Magyar Monarchia két társországában az Osztrák Császárságban és a Magyar Királyságban a két országgyülés eltérő módon szabályozta a témát. A magyar törvényhozás — az osztrák országgyülésnél jóval később és a közös haderö többszöri sürgetése 
nyomán - 1912-ben alkotta meg a kivételes hatalomról szóló magyar törvényt. ${ }^{42}$ A Magyar Királyságban tehát a rendvédelmi testületek a háború időszakában sem kerültek a haderő kompetenciájába. Ez alól a hadmüveleti területek jelentettek kivételt, amelyek mindenképp a haderő irányítása alá kerültek. ${ }^{43}$ A fövárosi rendőrség, annak részeként pedig a detektív testület a kormány belügyminiszter általi irányítása alatt maradt az I. világháború során mindvégig.

A második jelenség, amely jelentősen befolyásolta a fővárosi rendőrség detektív testületének az I. világháború alatti tevékenységét az a személyi állomány szükössége volt. A budapesti detektívek első rendszeresített létszáma csupán 36 fő volt, amely ugyan dinamikusan gyarapodott, azonban még békeidőszakban is elmaradt a létszámemelés az ügyek számának a növekedési ütemétől, illetve a feladatkörök gyarapodásától. ${ }^{44}$ 1914-ben a fővárosi rendőrség 2000 fő körüli létszámú őrszemélyzete mellett a detektív testületben 250 fö teljesített szolgálatot. Dr. DIETZ Károly 1917-ben a fökapitányi kinevezésekor a tiszti karnak 50, a felügyelői karnak 29, a detektív testületnek 400, az őrszemélyzetnek pedig 4000 főre való felemelését kérte.

A háború alatt — hasonlóan a társ rendvédelmi testületekhez — számos rendőrt behívtak katonai szolgálatra, illetve sokan önként jelentkeztek katonának. Az ily módon elvont személyi állomány pótlása pedig nem valósult meg. A hadsereg kötelékében szolgálatot teljesítő rendőrök visszairányítása az anyatestületükhöz szóba sem jöhetett ugyan, amennyiben azonban valamilyen csoda következtében erre mégis sor kerülhetett volna a harctéren elesettekre már többé nem lehetett számítani. ${ }^{45}$

$\mathrm{Az}$ úgynevezett katonai rendőrségnek a Magyar Szent Korona alá tartozó területeken nem volt joga ahhoz, hogy a polgári lakosság körében a rendet fenntartsa. Nem vehette át a rendvédelmi testületek feladatait és nem is utasíthatta azokat. Az 1917. év második felében megszervezésre kerülő katonai rendőrség a katonákat érintő ügyekben intézkedhetett. Mégis karhatalmi erőként, a rendvédelmi testületek megsegítéseként 
és azok átalárendeletségében, esetenként részt vehettek a rend fenn-tartására irányuló akcióban a polgári lakosság körében is ${ }^{46}$

A harmadik jelenséget - a békeviszony-lathoz képest jelentős mértékben kiszélesedő és szokatlan tartalmú feladatkör bővülés képezte. Az új feladatkörök skálája rendkívül széles volt, ide tartozott az élelmiszerek uzsoraszerü áremelkedésének a visszaszorításától, a középületek és közlekedési, valamint hírközlési csomópontok örzésén, a gyanús idegenek ellenőrzésén, a hadi ellátmánnyal üzérkedők kiszürésén, stb-n keresztül a kémek leleplezése is. Ennek során nem csupán a helyi lakosok törvénysértő magatartását kellett felderíteni, illetve megelőzni vagy meggátolni, hanem a nem csekély számban például Gallíciából és Kárpátaljából érkező törvénysértő magatartást megvalósító személyeket is figyelemmel kellett kísérni, a tevékenységüket megakadályozni. A kiterjedt háborús hatáskör és azokban a szaporodó ügyek egyre nagyobb terhet jelentettek a szúköd személyi állomány számára. ${ }^{47}$

A fővárosi rendőrség és annak részeként a detektív testület a számos nehézség ellenére is helytállt. Teendőit igyekezett minél eredményesebben megvalósítani, pedig közben még a területi illetékessége is gyarapodott. ${ }^{48}$

A fővárosi rendőrség detektívjei és örszemélyzeti állománya azonban az 1918-1919-es forradalmak tömegmegmozdulásának azonban már nem tudott gátat szabni. A szervezetet nem is ilyen céllal hozták létre, szervezeti felépítése, felszereltsége, a személyi állomány képzettsége, a rendelkezésre álló létszáma erre már tökéletesen alkalmatlan volt. Különösen így volt ez 1919 tavaszán, hiszen ,A 3000 fönyi rendörség nem szállhatott szembe a kommunistákhoz pártolt 14000 föt számláló helyörséggel és a nagyrészt felfegyverzett szociáldemokrata alakulatokkal. „,

A fővárosi rendőrség fiatal detektív testülete 1886-tól 1919-ig kiváló munkát végzett. E tevékenységnek több oka volt:

- A detektívek szellemi színvonala a kor átlagszínvonalához viszonyítva magas volt, mivel a testülethez való belépés elö- 
feltétele az érettségi volt, a dualizmus végén pedig az érettségizettek aránya a lakosság $1 \%$-át tette ki.

- A fővárosi rendőrségen belül is kedvező színvonalat jelentettek a detektívek, hiszen az őrszolgálati személyzettel szemben a négy elemi volt az állami iskolai végzettségbeli követelmény. Az őrszolgálati rendőri felügyelőknek pedig az állami iskolai végzettségbeli követelmény tekintetében az elvárás azonos volt a detektívekével.

-A detektívek az állami alkalmazottak általános ellátásával megegyezően - a társadalmi állásukhoz méltó életvitelhez szükséges feltételek biztosításában részesültek, amely független volt a piaci viszonyoktól. Ez az ellátási szint - a képzettségtől függően — stabil és a civil szférához képest irigylésre méltó volt.

- A detektívek szakmai irányítása a hazai és a külföldi szakmai tapasztalatok adaptálásán nyugvó magas színvonalú parancsnoki munkát megtestesítő tevékenység volt, melyet ugyanakkor az emberközpontúság is jellemzett, mivel a testület legnagyobb értékét a képzett személyi állomány alkotta, nem pedig a foglalkoztatottak létszáma.

- A detektív testület legfontosabb értéke azonban valószínüleg a szellemiségében rejlett. Nem egy-szerüen munkaszeretetről, hanem haza- és nemzetszeretetről volt szó, amely átsegített a testületi tagokat a nehéz történelmi idők viszontagságain igazi nemzeti szervezet volt, mely méltán vált a magyarországi rendőrségek államosításával a Magyar Királyi Állami Rendőrség detektív testületének a kiinduló bázisává. ${ }^{\mathbf{5 0}}$

A rövid történeti áttekintés során felfedezhető a detektívtestület és a jelenlegi rendvédelmi testületek nyomozó szervei között számos hasonlóság. Gondoljunk például a szolgálatszervezés során a mai napig általánosan használt csoportbeosztásokra, melyek megteremtették a mai tagozódást a nyomozók tekintetében, attól függően milyen jellegü büncselekmény nyomozását végzik.

Rablás, életellenes, gazdasági és egyéb büncselekmények nyomozásának speciális szakismereteket igénylő eseteire való tekintettel. A nyomozók képzése napjainkban is az általános 
rendészeti szakképesítést követően nyomozói szaktanfolyami formában van jelen. Azonban a múltból okulva fel kellene használnunk azokat a már kezdetben bevált jellemzőket is, amiknek jelenlegi hiánya véleményem szerint rontotta a nyomozói munka hatékonyságát. A korai elképzelések szellemében a detektívek elsősorban területi munkát végeztek, úgynevezett figyelöszolgálatot is elláttak. Megismerték a területükön uralkodó bünügyi helyzetet a rovott múltú személyeket, bünbarlangokat. Napjainkban néhány kerületi kapitányság esetében a nyomozók ki sem jutnak az utcákra, hiszen az egy före jutó ügyiratszám nemritkán a 40-et is meghaladja. Figyelembe kell persze vennünk a fluktuációt, a hiányos állományt, továbbá jogi hátterünk változásával a rendőrség hatásköre jóval szélesebb körü lett, ezáltal róva a megjelenő feladatoknak többszörösét a mai detektívekre.

Azonban ez a folyamat megfigyelhetö volt az 1896-ban megjelenő bünvádi perrendtartási törvény esetében is, ahol véleményem szerint a szervezet tudta tartani a lépést a növekvő feladatokkal. Ha a végeken szolgálatot ellátó nyomozóink több mozgási szabadságot kapnának a rájuk rótt feladatok csökkentésével, a területen gyüjtött információk felhasználásával eredményesebb bünüldöző, bünfel-derítő és bünmegelőző tevékenységet vihetnének véghez. A területi munka bünüldözésre gyakorolt pozitív hatásán kívül említésre méltó, hogy a szolgálati feladatok jobban elkülönültek egymástól. A detektívek nem végeztek közvetlenül nem a feladatkörükbe tartozó rendöri tevékenységet. Korunk rendörei, függetlenül attól, hogy milyen állománycsoportba tartoznak, sokszor végeznek nem közvetlenül a számukra elöírt tevékenységeket. Bizonyos esetekben előfordul, hogy a nyomozót is kiküldik a járőrök hatáskörébe tartozó címekre, átkísérésre, egyenruhás karhatalmat igénylő feladatokra. Természetesen erre minden bizonnyal a detektívek esetében is volt példa, de véleményem szerint csak szélsőségesebb esetekben.

Összességében a detektívtestület megalakulásával és változásával megfigyelhető egy felfelé ívelő folyamat, melynek során a szervezet úgy alakult, hogy reagálni tudjon a bünüldö- 
zés kihívásaira figyelembe véve a külföldi példákat és a hazai gyakorlatot. A testület szervezeti alakulása, melynek során egy osztályba központi irányítás alá vonták őket elösegítették a hatékonyabb gyorsabb munkavégzést. A szolgálati szabályzat megjelenésével, továbbá a detektívek szakosodásával konkretizálódtak feladataik, nyomozásuk célirányossá vált. Hatékonyságukat növelték továbbá a technikai újítások, nyilvántartások, daktiloszkópia bevezetése.

A detektívmunka történeti feltárása során elénk kerülő már bevált és müködő elemeket érdemes lenne felhasználnunk, hiszen a történelemböl és múltunkból tanulva elkerülhetjük, hogy ismét elkövessük a korábbi hibákat, legyen szó bármilyen rendvédelemmel kapcsolatos kérdéskörről.

\footnotetext{
$\frac{\text { Jegyzetek: }}{1 \text { ZACHAR: }}$

${ }^{1}$ ZACHAR: Az Osztrák-Magyar Monarchia örökös tartományainak rendvédelmi testületei. 20-24.p. ; Idem: Fejezetek az osztrák csendőrség történetéböl. 105-107.p. ; Idem: A Habsburg-hatalom és a magyar rendvédelem 148-149.p. ; DEÁK: Polgári átalakulás és neoabszolutizmus 1849-1867. ; Eadem: Államrendőrség és besúgó hálózat Magyarországon egy rendszerváltás fordulatos hónapjaiban 1860-1861. ; Eadem: Besúgólisták a neoabszolutizmus korából. ; Eadem: Egy régi politikai rendszerváltás és az államrendőrség 1867. ; Eadem: Ludasi Mór és a bécsi titkosrendőrség az 1860-as években. ; Eadem: Államrendőrség Magyarországon a Schmerlingi-provizórium időszakában. ; Eadem: Szigorúan ellenőrzött levelek. Az 1849. utáni politikai elit titkos postai megfigyelése. : Eadem: Államrendőrségi információs hálózat Magyarországon 18491867. Eadem: Államrendőrség Magyarországon, 1849-1867.

${ }^{2}$ CSIZMADIA: 79-80.p.

3 1870/XLII.tc. ; 1871/XVIII.tc.

${ }^{4}$ A polgári magyar állam katonailag szervezett fegyveres örtestülete volt:

- a Magyar Királyi Csendőrség 1881-1945 (Központi Nyomozó Parancsnokság 1930-tól);

- a Magyar Királyi Nemesi Testőrség 1867-1919 (nyomozó részleggel nem rendelkezett);

- a Magyar Királyi Darabont Testőrség 1904-1919 (nyomozó részleggel nem rendelkezett);

- a Magyar Királyi Testőrség 1920-1945 (nyomozó részleggel nem rendelkezett);
} 
- a Magyar Királyi Folyamőrség 1920-1939 (nyomozó részleggel rendelkezett); kezett);

- Magyar Királyi Vámőrség 1921-1931 (nyomozó részleggel rendel-

- Magyar Királyi Határőrség 1932-1938 (nyomozó részleggel rendelkezett)

- Magyar Királyi Képviselőházi Örség 1912-1945 (nyomozó részleggel nem rendelkezett).

A polgári magyar állam polgári fegyveres örtestületei voltak:

- Magyar Királyi Fővárosi Állami Rendőrség 1872-1919 (detektív testület 1885-töl); kezett);

- Magyar Királyi határrendőrség 1906-1918 (detektív csoporttal rendel-

- Magyar Királyi Fiumei Állami Rendőrség 1916-1918 (detektív csoporttal rendelkezett);

- Magyar Királyi Rendőrség 1931-1945 (detektív testület)

- Magyar Királyi Pénzügyőrség 1867-1945 (nyomozó „szakszolgálati ág” mủködött 1930-tól)

- Magyar Királyi Vám- és Adóőrség 1872-1886 (nyomozó részleggel nem rendelkezett).

5 PARÁDI: Rendvédelmi testületek a polgári magyar állam idöszakában 1867-1919. ; Idem: A dualista Magyarország belügyi szervei. ; Idem: A Magyar Királyság rendvédelme 1867-1919. ; Idem: Az Osztrák-Magyar Monarchia magyar-országi rendőrségei 1867-1919. ; Idem: A dualizmuskori magyar rendvédelem.

${ }^{6}$ 1872/XXXVI.tc. ; 1881/XXI.tc.

${ }^{7}$ „Sárga könyv”-nek nevezték a kortársak azt a sárga színű borítóba kötött könyvet, amelyben a szerzők összegyüjtötték a bünügyi eljárások kívánatos korabeli szabályait. E téma átfogó törvényi szabályozásának a létrejöttéig a szakma a „Sárga könyv”-ben foglaltakat tekintette mérvadónak.

${ }^{8}$ Ilyen rendbiztosok voltak: ZLINSZKY Károly, URS Nándor, MÁLtás Hugó.

${ }^{9}$ BORBÉLY - KAPY: 17.p.

${ }^{10} 1878 /$ V.tc. $\quad ; \quad 1879 /$ XL.tc.

${ }^{11}$ BORBÉLY - KAPY: op.cit. 15-17.p.

${ }^{12}$ Loc.cit. 21-22.p.

${ }^{13}$ A fơvárosi detektívtestület fönökei voltak: SPLÉNYI Ödön (1886-1889), SzOMBATFALVY Albert (bünügyi nyilvántartás, sajtóiroda. 1889-1899), RUTTNER Sándor (1899-1901), KRECSÁNYI Kálmán (daktiloszkópia 1901-1912), NAGY Károly (1912-1917), dr. JESZENSZKY Gellért (1917-1918). Loc.cit. 239-240.p.

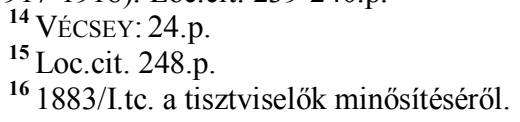


17 PARÁDI: Rendörtisztképzésünk hagyományai 1867-1945. ; Idem: Rendvédelmi tisztképzésünk hagyományai. ; Idem: A magyar rendőrtisztképzés tradíciói. ; Idem: Csendőrtisztképzés és a fizetési osztályba sorolt állami alkalmazottak szakvizsgarendszere.

${ }^{18}$ VÉCSEY: 247-249.p. ; PARÁDI: Rendvédelmünk képzési és képesítési rendszere 1867-1945.

${ }^{19}$ PARÁDI: Rendvédelem - karhatalom 1867-1945.

${ }^{20}$ PARÁDI: A csendőrség és a rendőrség biztosítási tradíciói. ; Idem: A magyar rendvédelem személyi állományának szociális viszonyai 1867-1945. ; Idem: A polgári magyar állam rendvédelmi testületeinek humán viszonyai 1867-1945. ; Idem: Az egységes állami fizetési rendszer és a szakterületi rendfokozati rendszerek a polgári magyar állam rendvédelmében.

${ }^{21} 1896 /$ XXXIII.tc. ; 3200/1899. (VIII. 15.) IM.r.

${ }^{22} 130$ 000/1899. (XII. 22.) BM.kr.

${ }^{23}$ RÉDEY: 9-18.p.

${ }^{24}$ A módszerrel antropológiai jellemzőket alkalmazva azonosították a személyeket, például a csontozat sajátosságai, fül, fej és végtagok mérete, egyéb jellemző ismertetőjegyek alapján.

${ }^{25}$ PERÉNYI: 59-71.p.

${ }^{26}$ PÜSPÖKY-KeLLER Mihály detektívfelügyelő napokig figyelt egy bérházat társával magukat rongyos ruházattal álcázva. A lakóházba ki és bejártak, találkoztak a lakókkal, de az emberek nem sejtették valódi kilétüket. Ezzel elegendő információt szereztek, hogy beazonosítsák és elfogják a hatóság által keresett csoportot. LEVICZKY Sándor detektív álruhában derített fel egy vendéglátó egység müködése mögé rejtett játékbarlangot. KLACsó Kálmán detektív postásnak álcázva magát nyert bebocsátást a keresett vagy bújtatott személyek lakásába. Dr. КотоғF Olivér detektívfelügyelö egy őrökkel és figyelőszemélyzettel ellátott játékbarlangot derített fel, oly módon, hogy elegáns úrnak öltözve magát bárónak kiadva, két hölgynek álcázott detektívtársával jutott be a belvárosi magánlakásba.

BORBÉLY - KAPY: op.cit. 254-258.p.

${ }^{27}$ Loc.cit. 249-250.p.

${ }^{28}$ VÉCSEY: op.cit. 43-45.p.

${ }^{29}$ A belügyi tárca élén TISZA Kálmán állt, aki egyben miniszterelnök is volt.

Tisza Kálmán (Geszt, Bihar vármegye, 1830. XII. 16. - Budapest, 1903. III. 23.) Nagybirtokos, a Határozati Párt elnöke, 1867-től a Balközép Párt alapító elnöke és vezére, 1875-től a Szabadelvű Párt alapító pártvezére.

- miniszterelnök: 1875. X. 20. - 1890. III. 13.

- belügyminiszter: 1875. III. 2. - 1878. X. 11. és 1878. XII. 5. - 1887. II. 11.

- pénzügyminiszter: 1878. X. 11. - 1878. XII. 5. és 1887. II. 11. - 1889. IV. 9.

- a király személye körüli miniszter: 1879. VII. 11. - 1879. X. 25.

- az ezredéves ünnepségek királyi biztosa: 1896. VI. 5. - 1896. VI. 8. BÖLÖNY: 294.p. 
${ }^{30}$ 1890-ben a belügyi tárcát gróf SZAPÁRY Gyula vezette.

Gróf SZAPÁRY Gyula (Pest, 1832. XI. 1. - Abházia Fiume közelében, 1905. I. 20.) Alispán, föispáni helytartó, királyi biztos, a magyar delegáció elnöke, tárnokmester, a Hitelbank elnöke.

- miniszterelnök: 1890. III. 13. - 1892. XI. 17.

- belügyminiszter: 1869. XI. 16. - 1870. VIII. 20. és 1873. III. 5. - 1875. III. 2. és 1890. III. 15. - 1892. XI. 19.

- pénzügyminiszter: 1873. III. 5. - 1875. III. 2.

- földmüvelésügyi miniszter: 1889. VI. 16. - 1890. III. 15.

- földművelés-, ipar- és kereskedelemügyi miniszter: 1889. IV. 9. - 1889. VI. 15.

- közmunka és közlekedésügyi miniszter: 1880. IV. 14. - 1880. IV. 24. BÖLÖNY: op.cit. 284-285.p.

${ }^{31}$ BORBÉLY - KAPY: op.cit. 25.p.

${ }^{32}$ Loc.cit.

${ }^{33} 9$ 389/1885. (II. 14.) BM.r.

${ }^{34}$ A fővárosi rendőrségre vonatkozó szabályokat elöször KRECSÁNY Kálmán kerületi kapitány gyüjtötte össze és rendszerezte, melyet később RÉDEY Miklós rendőrtiszt pontosított évente.

BORBÉLY - KAPY: op.cit. 26.p.

A testületre vonatkozó - immár az államosított magyar rendőrség egészére kiterjedően — újabb szabálygyüjtemény létrehozására 1926-ban került sor.

NÉMETHY - TÖRÖK

${ }^{35}$ BORBÉLY - KAPY: op.cit. 25.p.

${ }^{36}$ Nem a fővárosi rendőrség kötelékéből került kinevezésre THAISZ Elek (1873-1884), JEKKELFALUSY Lajos (1884-1885), TÖRÖK János (1885-1892), RudNAY Béla (1896-1906). Dr. BodA Dezső határeset, mivel a fővárosi rendőrség kötelékéből debreceni kormánybiztossá kinevezett BoDA Dezsőt feladata kiváló teljesítése nyomán nevezték ki a fővárosi rendőrség élére. A fővárosi rendőrség személyi állományából nevezték ki a föváros rendőrfőkapitányává dr. SÉlLeY Sándort (1892-1895), dr. SÁNDOR Lászlót (1917-1918) és dr. DiETz Károlyt (1918-1919).

BORBÉLY - KAPY: op.cit. 75-91.p.

${ }^{37}$ TISZA

${ }^{38}$ PARÁDI: Az államfő testőrségei az Osztrák-Magyar Monarchiában.

${ }^{39}$ Idem: A Magyar Királyi Csendörség. Az elsö magyar polgári, központositott közbiztonsági örtestület 1881-1945.

${ }^{40}$ 1903/VIII.tc. ； 5 692/1905. (XII.29.) ME.r. ； 91 000/1905. (XII. 29.) BM.kr.

${ }^{41}$ VÉCSEY: op.cit. 39.p.

${ }^{42}$ 1912/LXII.tc.

${ }^{43}$ PARÁDI: Határrendőrség a történelmi Magyarországon 1906-1918. ; MEZEY

${ }^{44}$ Például a kivándorlási törvény intézkedéseinek ellenőrzése a pályaudvari kirendeltség feladatává is vált, amely az őrszemélyzet és a detektív testület tagjaira egyaránt a korábbinál lényegesen több teendőt rótt.

BORBÉLY - KAPY: op.cit. 31.p. 
45 A fővárosi rendőrség tagjai közül az I. világháború során a harctéren hősi halált halt, vagy sebesülésbe és betegségébe belehalt, továbbá eltünt összesen 57 fö.

Loc.cit. 39-40.p.

46 SUBA

47 A budapesti detektívek 1915-ben 37077 megbízást kaptak, amelyből 33270 nyomozás volt sikeres. 1916-ban azonban már 81723 aktát intéztek el.

BORBÉLY - KAPY: op.cit. 37-38.p.

48 1916-ban a fővárosi rendőrség hatáskörét kiterjesztették — az akkor még Budapest agglomerációjába tartozó - csepel községre is. Ez nem az első eset volt, mivel a fóvárosi rendőrség létrehozása óta több agglomerációs település is a hatáskörébe vontak.

1916/XXXVIII.tc.

${ }^{49}$ BORBÉLY - KAPY: op.cit. 48.p.

505 047/1919.ME.r.

Jegyzetekben alkalmazott röviditések:

MONOGRÁFIÁK, KISMONOGRÁFIÁK ÉS HASONLÓ JELLEGÜ KÖTETEK

BORBÉLY - KAPY

BORBÉLY Zoltán - KAPY Rezső (szerk.): A 60 éves magyar rendörség 1881-1941. Budapest, 1942, Halász Irodalmi és Könyvkiadó Vállalat. 594 p.

BÖLÖNY

BölÖNY József: Magyarország kormányai 1848-1975. Budapest, 1978, Akadémia. 328 p. HU-ISBN 963051242 v. /A Magyar Országos Levéltár Kiadványai, IV. - Levéltártan és történeti forrásdokumentumok, 2./ HU-ISSN 0441-4985.

CSIZMADiA

Csizmadia Andor: A magyar közigazgatás fejlödése a XVIII. századtól a tanácsrendszer létrejöttéig. Budapest, 1976, Akadémia Kiadó. 560 p. HU-ISBN 9630507137. 
DEÁK: Polgári átalakulás és neoabszolutizmus 1849-1867.

PERÉNYI

PARÁDI: A Magyar Királyi Csendörség. Az elsö magyar polgári, központositott közbiztonsági örtestület 1881-1945.

RÉDEY

TiszA

VÉCSEY

\section{TANULMÁNYOK}

DEÁK: Államrendőrség és besúgó hálózat Magyarországon egy rendszerváltás fordulatos hónapjaiban 1860-1861.

DEÁK: Besúgólisták a neoabszolutizmus korából.

DEÁK: Egy régi politikai rendszerváltás és az államrendőrség 1867.
DeÁK Ágnes: Polgári átalakulás és neoabszolutizmus 1849-1867. Budapest, 2009, Kossuth. 104 p. HU-ISBN 978963 0956932.

PeréNyI Roland: $A$ bün nyomában. $A$ budapesti bünözés társadalomtör-ténete 1896-1914. Budapest, 2012, L'harmattan. 318 p. HU-ISBN 978963236554 1. /A múlt ősvényein./ HU-ISSN 1587-3153.

PARÁDI József: A Magyar Királyi Csendörség. Az első magyar polgári, központositott közbiztonsági örtestület 18811945. Budapest, 2012, Szemere Bertalan Magyar Rendvédelem-történeti Tudományos Társaság. 281 p. HU-ISBN 978963 0847940 . /A magyar rendvédelem-történet öröksége, 2./ HU-ISSN 2062-8447.

RÉDEY Miklós: A nyomozási eljárás nehézségei. Budapest, 1901, Légrády Testvérek. 68 p.

Tisza Miksa: Magyarország rendőrségeinek története a legrégibb időktöl 1912ig. Igló, 1913, Szepesi Lapok Nyomda. $327 \mathrm{p}$.

VÉCSEY Leó (szerk.): $A 40$ éves budapesti detektív testület jubiláris albuma 1886-1926. Budapest, 1927, A Magyar Királyi Államrendörség Detektívtestületének Nyugdíjpótló és Segélyező Egyesülete. $320 \mathrm{p}$.

DEÁK Ágnes: Államrendőrség és besúgó hálózat Magyarországon egy rendszerváltás fordulatos hónapjaiban 18601861. Századok, CXL. évf. (2006) 6. sz. 1551-1774. p. HU-ISSN 0039-8098.

DEÁK Ágnes: Besúgólisták a neoabszolutizmus korából. Aetas, XXI.évf. (2006) 4.sz. 21-44.p. HU-ISSN 1785-9943.

DEÁK Ágnes: Egy régi politikai rendszerváltás és az államrendőrség 1867. Történelmi Szemle, XLIX.évf. (2007) 3.sz. 351-372. p. HU-ISSN 0040-9634. 
DEÁK: Ludasi Mór és a bécsi titkosrendőrség az 1860-as években.

DEÁK: Államrendőrség Magyarországon a Schmerlingiprovizórium időszakában.

DEÁK: Szigorúan ellenőrzött levelek. Az 1849. utáni politikai elit titkos postai megfigyelése.

DEÁK Ágnes: Államrendörségi információs hálózat Magyarországon 1849-1867.

MEZEY

PARÁDI: A dualista Magyarország belügyi szervei.
DEÁK Ágnes: Ludasi Mór és a bécsi titkosrendőrség az 1860-as években. In RESS Imre — SzABÓ Dániel (szerk.): $A$ Lajtán innen és túl. Elektronikus ünnepi tanulmányok Somogyi Éva 70. születésnapjára. Budapest, 2007, MTA Történelemtudományi Intézet. 131-134.p. HU-ISBN 9789639627178.

DEÁK Ágnes: Államrendőrség Magyarországon a Schmerlingi-provizórium időszakában. Századok, CXLII.évf. (2008) 3.sz. 727-771.p. HU-ISSN 0039-8098.

DEÁK Ágnes: Szigorúan ellenörzött levelek. Az 1849. utáni politikai elit titkos postai megfigyelése. Múlt-kor, II.évf. (2011) tavasz. 53-56.p. HU-ISSN 2061-3563.

DEÁK Ágnes: Államrendőrségi információs hálózat Magyarországon 1849-1867. 8189.p. In Csóka Ferenc (szerk.): Szakszolgálat Magyarországon, avagy tanulmányok a hírszerzés és titkos adatgyüjtés világából 1785-2011. Budapest, 2012, Nemzetbiztonsági Szakszolgálat. 81-92.p. HU-ISBN 9789630832113.

MezEY Barna: A kivételes Hatalom. Rendvédelem-történeti Füzetek (Acta Historiae Praesidii Ordinis), IV.évf. (1994) 5.sz. 4-6.p. HU-ISSN 1216-6774. A tanulmány korábbi változata 1993 szeptember 21-én Budapesten hangzott el a Szemere Bertalan Magyar Rendvédelemtörténeti Tudományos Társaság által szervezett rendvédelem-történeti tudományos konferen-ciasorozatnak a „Háború, forradalom, trianon" címü V. konferenciáján. A publikált tanulmány az előadás javított, bővített és átdolgozott változata.

PARÁDI József: A dualista Magyarország belügyi szervei. Belügyi Szemle, XXXIV.évf. (1986) 4.sz. 45-50.p. HUISSN 0133-6738. 
PARÁDI: Rendőr tisztképzésünk hagyományai 18671945.

PARÁDI: A rendőrség és a csendörség személyi állományának biztosítási tradíciói.

PARÁDI: Rendvédelmi tisztképzésünk hagyományai.

PARÁDI: A Magyar Királyság rendvédelme 1867-1919.

PARÁDI: Az Osztrák-Magyar Monarchia magyarországi rendőrségei 18671919.
PARÁDI József: Rendőr tisztképzésünk hagyományai 1867-1945. 35-51.p. In DÁNOS Valér (szerk.): A rendőrképzés reformja a kelet-európai változások tükrében. Budapest, 1991, BM Rendészeti Kutató Intézet. /Tanulmányok a rendészet köréből./ A tanulmány korábbi változata 1991. november 12-én Balatonföldváron hangzott el a Rendőrtiszti Főiskola által szervezett rendvédelmi szakképzési konferencián. A publikált tanulmány az előadás javított, bővített és átdolgozott változata.

PARÁDI József: A rendőrség és a csendőrség személyi állományának biztosítási tradíciói. RTF Föiskolai Figyelö Plusz, IV.évf. (1993) 1.sz. 130-136.p. HU-ISSN 0866-4404.

PARÁDI József: Rendvédelmi tisztképzésünk hagyományai. Rendészeti Szemle, XLV.évf. (1997) 4.sz. 101-109.p. HUISSN 1789-4689.

PARÁDI József: A Magyar Királyság rendvédelme 1867-1919. Rendvédelemtörténeti Füzetek (Acta Historiea Preasidii Ordinis), IX.évf. (1999) 10.sz. 98147.p. HU-ISSN 1216-6774. A tanulmány korábbi változata 1998. szeptember 22-én Budapesten hangzott el a Szemere Bertalan Magyar Rendvédelem-történeti Tudományos Társaság által szervezett rendvédelem-történeti tudományos konferencia-sorozatnak ,A nyugati rendvédelem hatása a XIX-XX. századi magyar rendvédelemre" címü $\mathrm{X}$. konferenciáján. A publikált tanulmány az előadás javított, bővített és átdolgozott változata.

PARÁDI József: Az Osztrák-Magyar Monarchia magyarországi rendőrségei 1867-1919. Rendvédelem-történeti Füzetek (Acta Historiae Praesidii Ordinis), XI. évf. (2005) 13.sz. 97-104.p. HU-ISSN 1216-6774. A tanulmány korábbi változata 2000. március 19.-én, Párizsban hangzott el a Szemere Bertalan Magyar 
PARÁDI: A magyar rendör tisztképzés tradíciói 1867-1945.

PARÁDI: A csendör tisztképzés és a fizetési osztályba sorolt állami alkalmazottak szakvizsga rendszere.

PARÁDI József: Rendvédelmünk képzési és képesítési rendszere 18671945.
Rendvédelem-történeti Tudományos Társaság által szervezett rendvédelem-történeti tudományos konferenciasorozatnak „A közbiztonság közös európai örökségünk" címü XIII. konferenciáján. A publikált tanulmány az előadás javított bővített és átdolgozott változata.

PARÁDI József: A magyar rendőr tisztképzés tradíciói 1867-1945. Rendvédelem-történeti Füzetek (Acta Historiae Praesidii Ordinis), XIII.évf. (2007) 16.sz. 94-99.p. HU-ISSN 1216-6774. A tanulmány korábbi változata 2002. november 12-én, Budapesten hangzott el a Szemere Bertalan Magyar Rendvédelem-történeti Tudományos Társaság által szervezett rendvédelem-történeti tudományos konferencia-sorozatnak a ,A rendvédelmi szakképzés története" címü XVI. konferenciáján. A publikált tanulmány az előadás javított, bővített és átdolgozott változata.

PARÁDI József: A csendôr tisztképzés és a fizetési osztályba sorolt állami alkalmazottak szakvizsga rendszere. Rendvédelem-történeti Füzetek (Acta Historiae Praesidii Ordinis), XIII.évf. (2007) 16.sz. 100-104.p. HU-ISSN 1216-6774. A tanulmány korábbi változata 2002. november 12-én, Budapesten hangzott el a Szemere Bertalan Magyar Rendvédelem-történeti Tudományos Társaság által szervezett rendvédelem-történeti tudományos konferenciasorozatnak. „A rendvédelmi szakképzés története" címü XIV. konferenciáján. A publikált tanulmány az előadás javított, bővített és átdolgozott változata.

PARÁDI József: Rendvédelmünk képzési és képesítési rendszere 1867-1945. Rendvédelem-történeti Füzetek (Acta Historiae Praesidii Ordinis), XIII.évf. (2007) 16.sz. 90-93.p. HU-ISSN 1216-6774. A tanulmány korábbi változata 2002. november 12-én Budapesten hangzott el a Szemere Bertalan Magyar Rendvédelemtörténeti Tudományos Társaság által szer- 
vezett rendvédelem-történeti tudományos konferenciasorozatnak „A rendvédelmi szakképzés története" címü XVI. konferenciáján. A publikált tanulmány az elöadás javított, bővített és átdolgozott változata.

PARÁDI: A magyar rendvédelem személyi állományának szociális viszonyai 1867-1945.

PARÁDI: A dualizmuskori magyar rendvédelem.

PARÁDI: A polgári magyar állam rendvédelmi testületeinek humán viszonyai 1867-1945.
PARÁD József: A magyar rendvédelem személyi állományának szociális viszonyai 1867-1945. Rendvédelem-történeti Füzetek (Acta Historiae Praesidii Ordinis), XV.évf. (2008) 17.sz. 57-64.p. HUISSN 1216-6774. A tanulmány korábbi változata 2003. november 11-én Budapesten hangzott el a Szemere Bertalan Magyar Rendvédelem-történeti Tudományos Társaság által szervezett rendvédelem-történeti tudományos konferencia-sorozatnak a „A rendvédelem humán viszonyai" címü XVII. konferenciáján. A publikált tanulmány az előadás javított, bővített és átdolgozott változata.

PARÁDI József: A dualizmuskori magyar rendvédelem. Rendvédelem-történeti Füzetek (Acta Historiae Praesidii Ordinis), XVIII.évf. (2010) 21.sz. 6684.p. A tanulmány korábbi változata 2007. október 5-én, Budapesten hangzott el a Szemere Bertalan Magyar Rendvédelem-történeti Tudományos Társaság által szervezett rendvédelem-történeti tudományos konferencia-sorozatnak „, rendvédelem fejlödése a XIX-XX. században" címü XXI. konferenciáján. A publikált tanulmány az előadás javított, bővített és átdolgozott változata.

PARÁDI József: A polgári magyar állam rendvédelmi testületeinek humán viszonyai 1867-1945. Rendvédelem-történeti Füzetek (Acta Historiae Praesidii Ordinis), XIX. évf. (2010) 22. sz. 92-114. p. A tanulmány korábbi vál-tozata 2008. október 10-én Budapesten hangzott el, a Szemere Bertalan Magyar Rendvédelemtörténeti Tudományos Társaság által szervezett rendvédelem-történeti tudományos 
PARÁDI: Rendvédelem karhatalom 1867-1945.

PARÁDI: Az egységes állami fizetési rendszer és a szakterületi rendfokozati rendszerek a polgári magyar állam rendvédelmében.

PARÁDI: Az államfő testőrségei az Osztrák-Magyar Monarchiában. konferenciasorozatnak „Másfél évszázad rendszerváltozásainak hatásai a nemzeti rendvédelmünkre" címü XXII. konferenciáján. A publikált tanulmány az elöadás javított, bővített és átdolgozott változata.

PARÁDI József: Rendvédelem karhatalom 1867-1945. Rendvédelem-történeti Füzetek (Acta Historiae Preasidii Ordinis), XX. évf. (2011) 23.sz. 111-123.p. A tanulmány korábbi változata 2009. október 9-én Budapesten hangzott el, a Szemere Bertalan Magyar Rendvédelem-történeti Tudományos Társaság által szervezett rendvédelem-történeti tudományos konferencia-sorozatnak „A kiegyezéstöl az ezredfordulóig felszámolt országos hatáskörü magyar rendvédelmi testületek." címü XXIII. konferenciáján. A publikált tanulmány az előadás javított, bővített és átdolgozott változata.

PARÁDI József: Az egységes állami fizetési rendszer és a szakterületi rendfokozati rendszerek a polgári magyar állam rendvédelmében. Rendvédelem-történeti Füzetek (Acta Historiae Praesidii Ordinis), XXII.évf. (2012) 26.sz. 105-119.p. A tanulmány korábbi változata 2011. november 11-én, Budapesten hangzott el, a Szemere Bertalan Magyar Rendvédelem-történeti Tudományos Társaság által szervezett rendvédelem-történeti tudományos konferenciasorozatnak ,Militarizmus és demilitarizmus a XIX-XX. századi magyar állam rendvédelmében" címü XXV. konferenciáján. A publikált tanulmány az előadás javított, bővített és átdolgozott változata.

PARÁDI József: Az államfő testőrségei az Osztrák-Magyar Monarchiában. Rendvédelem-történeti Füzetek (Acta Historiae Preasidii Ordinis), XXIII. évf. (2013) $27-$ 28-29-30.sz. 155-160.p. HU-ISSN 12166774. A tanulmány korábbi változata 2011. november 11-én, Budapesten hangzott el a Szemere Bertalan Magyar Rend- 
PARÁDI: Rendvédelmi testületek a polgári magyar állam időszakában.
PARÁDI: Határrendőrség a történelmi Magyarországon 1906-1918.
SUBA védelem-történeti Tudományos Társaság által szervezett rendvédelem-történeti tudományos konferencia-sorozatnak a ,,Militarizmus és demilitarizmus a XIX-XX. századi magyar rendvédelem-ben" címü XXVI. konferenciáján. A publikált tanulmány az előadás javított, bővített és átdolgozott változata.

PARÁDI József: Rendvédelmi testületek a polgári magyar állam időszakában. Rendvédelem-történeti Füzetek (Acta Historiae Praesidii Ordinis), XXIII. évf. (2013) 31-32-33-34.sz. 121-146.p. HUISSN 1216-6774. A tanulmány korábbi változata 2014. február 21-én, Budapesten hangzott el, a Szemere Bertalan Magyar Rendvédelem-történeti Tudományos Társaság által szervezett rendvédelemtörténeti tudományos szimpozion-sorozatnak ,A kivételes hatalom és a közbiztonság” címü XIV. szimpozionján. A publikált tanulmány az előadás javított, bővített és átdolgozott változata.

PARÁDI József: Határrendőrség a történelmi Magyarországon 1906-1918. Rendvédelem-történeti Füzetek (Acta Historiae Praesidii Ordinis), XXVI.évf. (2016) 51.sz. HU-ISSN 1216-6774. A tanulmány korábbi változata 2016 október 28-án, Budapesten hangzott el, a Szemere Bertalan Magyar Rendvédelem-történeti Tudományos Társaság által szervezett rendvédelem-történeti tudományos konferencia-sorozatnak „A katonailag szervezett fegyveres örtestületek és a polgári fegyveres örtestületek a XIX-XX. századi magyar állam határőrizetében" címü XXXI. konferenciáján. A publikált tanulmány az előadás javított, bővített és átdolgozott változata.

SuBA János: A katonai rendörség felállitása a hátországban 1917-ben. Rendvédelem-történeti Füzetek (Acta Historiae Praesidii Ordinis), XV.évf. (2008) 18. sz. 143-155.p. A tanulmány korábbi változata 
ZACHAR: Az Osztrák-Magyar Monarchia örökös tartományainak rendvédelmi testületei.
ZACHAR: Fejezetek az osztrák csendőrség történetéből.
2004. október 13-án Budapesten hangzott el a Szemere Bertalan Magyar Rendvédelem-történeti Tudományos Társaság által szervezett rendvédelem-történeti tudományos konferencia-sorozatnak „Karhatalmi feladatok a bünmegelözés és a békefenntartás szolgálatában Euró-pában a XIX-XX. században” címü XVIII. konferenciáján. A publikált ta-nulmány az előadás javított, bővített és átdolgozott változata.

ZACHAR József: Az Osztrák-Magyar Monarchia örökös tartományainak rendvédelmi testületei. Rendvédelem-történeti Füzetek (Acta Historiae Praesidii Ordinis), HU-ISSN 1216-6774. I.évf. (1991) 1.sz. 17-29.p. HU-ISSN 1216-6774. A tanulmány korábbi változata 1990. április 24.-én Budapesten hangzott el a Szemere Bertalan Magyar Rendvédelem-történeti Tudományos Társaság által szervezett rendvédelem-történeti tudományos konferencia-sorozatnak „A magyar rendvédelmi testületek és az önkormányzati szervek kapcsolata 1848-1945" címü I. konferenciáján. A publikált tanulmány az előadás javított, bővített és átdolgozott változata.

ZACHAR József: Fejezetek az osztrák csendőrség történetéből 1849-1918. Rendvédelem-történeti Füzetek (Acta Historiae Praesidii Ordinis), VII.évf. (1997) 8.sz. 105-109.p. HU-ISSN 1216-6774. A tanulmány korábbi változata 1996. október 29-én Budapesten hangzott el a Szemere Bertalan Magyar Rendvédelem-történeti Tudományos Társaság által szervezett rendvédelem-történeti tudományos konferencia-sorozatnak „A napóleoni közbiztonsági örtestület útja Párizstól Itálián és Ausztrián keresztül — Budapestig." Címü VIII. konferenciáján. A publikált tanulmány az előadás javított, bővített és átdolgozott változata. 
ZACHAR: A Habsburg-hatalom és a magyar rendvédelem.
ZACHAR József: A HABSBURG-hatalom és a magyar rendvédelem. Rendvédelemtörténeti Füzetek (Acta Historiae Praesidii Ordinis), IX.évf. (2005) 14.sz. 146149.p. HU-ISSN 1216-6774. A tanulmány korábbi válto-zata 2000. november 8-án, hangzott el, Budapesten a Szemere Bertalan Magyar Rendvédelem-történeti Tudományos Társaság által szervezett magyar rendvédelem-történeti tudományos konferencia-sorozatnak , $A z$ ezeréves magyar rendvédelem" címü XIV. konferenciáján. A publikált tanulmány az előadás javított, bövített és átdolgozott változata.

\section{REGISZTRÁLT KÉZIRATOK}

DEÁK: Államrendörség Magyarországon, 18491867.
DEÁK Ágnes: Államrendőrség Magyarországon, 1849-1867. Akadémiai doktori értekezés. (MTA) Kézirat. Budapest, 2013.

\section{JOGSZABÁLYGYÜJTEMÉNYEK}

NÉMETHY — TÖRÖK

\section{JOGSZABÁLYOK}

1870/XLII.tc.

1871/XVIII.tc.

1872/XXXVI.tc.

1878/V.tc.

1879/XL.tc.

1881/XXI.tc.
NÉMETHY Tihamér - TÖRÖK Lajos: Rendöri vonatkozású törvények, rendeletek és eljárási szabályok gyüjteménye. Budapest, 1926, Editor. 822 p. /Rendörtisztviselők zsebkönyvtára./

1870/XLII.tc. a törvényhatósági hatáskörröl.

1871/XVIII.tc. a községek rendezéséröl.

1872/XXXVI.tc. Buda-Pest fővárosi törvényhatóság alakításáról és rendezéséröl.

1878/V.tc. a magyar büntetőtörvénykönyv a büntettekről és vétségekről.

1879/XL.tc. a magyar büntetötörvénykönyv a kihágásokról.

1881/XXI.tc. Budapest fövárosi rendörségröl. 
1883/I.tc.

1896/XXXIII.tc.

1903/VIII.tc.

1912/LXII.tc.

1916/XXXVIII.tc.

5692/1905. (XII.29.) ME.r.

91 000/1905. (XII. 29.) BM.kr.

9 389/1885. (II. 14.) BM.r.

3200/1899. (VIII. 15.)

IM.r.
1883/I.tc. a tisztviselők minősítéséről.

1896/XXXIII.tc. a bünvádi perrendtartásról.

1903/VIII.tc. a határrendőrségröl.

1912/LXII.tc. a háború esetére szóló kivételes intézkedésekről.

1916/XXXVIII.tc. a Budapest Székesfővárosi Magyar Királyi Állami Rendörség hatáskörének Csepel község területére való kiterjesztéséről.

5 692/1905. (XII.29.) ME.r. a határrendőrségről szóló 1903/VIII.tc. életbe léptetéséről.

Magyarországi rendeletek Tára, XXXIX.évf. (1905) I.füzet. 1455.p.

91 000/1905. (XII. 29.) BM.kr. valamennyi törvényhatósághoz Fiume város kivételésel a határrendőrségről szóló 1903/VIII.tc. életbe léptetésének a végrehajtásáról.

Magyarországi rendeletek Tára, XXXIX.évf. (1905) I.füzet. 1455-1541.p.

9 389/1885. (II. 14.) BM.r. tolonczszabályzat kibocsátása tárgyában.

Magyarországi Rendeletek Tára, XIX.évf. (1885) I.füzet. 164-243.p.

3200/1899. (VIII. 15.) IM.r. a bünvádi perrendtartásról szóló 1896/XXXIII.tc. életbeléptetése tárgyában.

Igazságügyi Közlöny, VIII.évf. (1899) 8.sz. 229-234.p. 
130 000/1899. (XII. 22.) — _ 130 000/1899. (XII. 22.) BM.kr. a bünBM.kr. vádi perrendtartásról szóló 1896/XXXIII.tc. életbe léptetése alkalmából a nyomozó rendőri hatóságok és közegek részére kibocsátott Utasítás tárgyában.

Magyarországi Rendeletek Tára, XXXIII.évf. (1899) II.füzet. 2416-2417.

5 047/1919. (X. 1.) ME.r. _ _ 5 047/1919. (X. 1.) ME.r. a rendőrség államosításáról.

Magyarországi Rendeletek Tára, LIII.évf. (1919) I.füzet. 752-767.p. 